\title{
THE IMPLICATION OF TEACHER PROFESSIONALISM IMPROVEMENT AND LEARNING EVALUATION TECHNIQUES TOWARD MADRASAH TEACHER PERFORMANCE
}

\author{
Deden Ibnu Aqil*, Nur Amega Setiawati dan Fajar Kurniadi \\ Economics Education Study Program, Universitas Indraprasta PGRI, Jakarta, Indonesia \\ *Email : den.aqil@gmail.com
}

Website: http://jurnal.uin-antasari.ac.id/index.php/itjik

Received: 28 May 2020; Accepted: 14 December 2020; Published: 17 December 2020

\begin{abstract}
The ability of a teacher to understand his or her competence greatly determines the success of his students, because students will develop if the teachers are able to develop themselves by increasing their professionalism. This research method used a quantitative approach with a sample of teachers at Madrasah Ibtidaiyah Miftahul Falah Depok. The results of this study indicate that there is no positive and significant influence both activities to increase teacher professionalism and learning evaluation techniques on teacher performance at the Mifathul Falah Sawangan school, Depok.
\end{abstract}

Key Words: professionalism; learning evaluation techniques; performance of madrasah teachers.

\section{INTRODUCTION}

The role of the teacher in education is important, because teacher as the main center of role model for students in school. The ability of teacher in comprehending the competence determines the success of students, as students will grow if the teachers are able to foster their profesionalism.

Law No. 14 Year 2005 states that 'Teachers' professional empowerment activities can be carried out through selfdevelopment activities carried out in a democratic, fair, non-discriminatory and sustainable manner by upholding human rights, religious values, cultural values and national diversity as well as professional code of ethics".

Based on the informal interview to teachers that problem existed today is teachers who are under Ministry of Religion get less attention from development side. It can be seen from the indikasi the lack of training carried out by the Ministry. The lack of teacher profesionalism development in form training or workshop causes teachers understand less the meaning of their profesion as madrasah teachers in which similar to elementary teachers.

Likewise it happened at Madrasah Ibtidaiyah Miftahul Falah, most teachers do not exactly understand the meaning of of the teaching profession itself, so that it has impact to teachers performance which is not accordance with the main duties and functions of the teacher as a profession that demands professionalism on duty.

Based on the interview with Ibu Arti, S. Pd.I as vice of principal which handled curriculum side, she states that "most teachers in madrasah are not yet skilled in making lesson plan, do not have relevant teaching resourches to the curriculum used, the teaching methods are still conventional and not yet skilled in making accurate test items according to indicators". Hence, it is necessary to hold activities to increase teacher professionalism so that teachers get enlightenment that can motivate them to improve their performance. 
According to Manullang (in Musfah, 2015: 11) states that" one way to develop the workforce in an organization or in an institution such as a school is by holding training". According to Jejen Musfah (2015: 11) each teachers at school need activities to increase their professionalism by training in purpose to add insight and skills. Such a thing will motivate teachers to develop all their competencies and provide encouragement so that they can continue to learn throughout their lives.

According to Gunawan (2011) teachers are charged to carry out teaching hours $24 \mathrm{x}$ face to face. This is very time consuming to develop their competence. On the other hand, teachers must set an example for lifelong learning through participation in various seminars, trainings, workshops that can improve teacher competence.

Teacher competency development can be achieved through learning from various training programs carried out through schools and outside schools. So the author needs to observe the extent to which the implications of these enhancement activities in terms of performance, whether teacher performance has increased or not.

The research objectives were to determine the effect of activities to increase teacher professionalism, to determine the effect of activities to improve learning evaluation techniques and to determine the effect of activities to increase teacher professionalism and evaluation techniques on teacher performance. The benefit of this research is to provide scientific information that training activities to improve teacher professionalism can affect teacher performance and skills in making student exam tests.

Professional teachers are teachers who are able to realize all their competences in educating and teaching students as their main task. This can be measured through the Teacher and Lecturer Law No.14 of 2005 which states that professional teachers have the characteristics of mastering Pedagogic, professional, Personality and Social competencies.

Teacher is a noble job who is at the highest level in the education system and has strong autonomy in carrying out its duties at school. According to Sagala (2009), the first task is to prepare learning administration according to the objectives set. Second, providing material and guiding students. Third, assess student learning outcomes. The fourth is carrying out activities related to enrichment of learning.

A good teacher is a teacher who is a role model for his students, one of which is a person who always tries to improve his knowledge and develop his skills so as not to be left behind in the information of his time. If at school the teacher carries out his duties as an educator and teacher, outside of school he remains a teacher for the community with good behavior and should be emulated as a source of exemplary.

In today's real conditions, a teacher should not only emphasize the aspects of teaching or knowledge transfer or just stop until the test results, but on the aspects of how the knowledge obtained by students can be implemented properly in the form of thinking, acting and behaving.

The results of Mawardi's (2019) research at Madrasah Ibtidaiyah Negeri in Sabang City show that the competence of teachers in compiling lesson plans is still low, as a result of the teacher's lack of knowledge about this arrangement, which is due to lack of guidance and training from related agencies, including nongovernmental organizations. other governments.

A research by Ernawati dan Safitri (2017) states that the difficulty of the teacher in making lesson plans is the lack of training. 
In preparing the lesson plan, it ends with an assessment for learning evaluation. Most of the learning evaluations carried out by the teacher are only seen from the results of exams or assignments. This is what teachers need to do to assess students not only from the cognitive side, but also from the affective and psychomotor sides.

Thus it is necessary to know how the effect of these professionalism activities and also learning evaluation techniques on teacher performance in schools in making assessments or evaluating learning.

\section{RESEARCH METHODOLOGY}

This research uses quantitative research. This research took place at Madrasah Ibtidaiyah Miftahul Falah Sawangan Depok, which was conducted from March to June 2019. The population in this study were teachers. This research was conducted in 15 people. In this study, the sample was not used because the object under study was the entire population in the school. So all teachers are researched as a whole to be the object of research without having to take a certain number of samples.

Primary data is data directly obtained by researchers from respondents, so to extract information from these data it is necessary to use data collection techniques with questionnaires, namely by providing a list of questions to respondents, in addition to conducting interviews.

Secondary data comes from related supporting sources and literature studies (books, teacher documents, internet and others) to obtain information related to research. The data collection techniques used in this study were questionnaires, interviews, observation, documentation. To measure the research instrument used validity and reliability. The classical assumption test is carried out as a condition of whether the data obtained is suitable for processing after it is tested by regression analysis.

\section{RESULT AND DISCUSSION}

Research data processing was processed using descriptive statistics. Descriptive statistics used include; The mean (average), median, mode (mode), standard deviation, minimum and maximum values and data are presented in the frequency distribution through the SPSS 20.00 application program as well as their analysis and interpretation.

\section{A. Data Description}

1. Teacher Professionalism Training $\left(\mathrm{X}_{1}\right)$ The average value of teacher professional variables is 30.4667. The standard deviation value is 9,59067 . The maximum value is 40.00 and the minimum value is 15.00 .

2. Learning Evaluation Technique $\left(\mathrm{X}_{2}\right)$

The average value of the learning evaluation technique variable is 35,333 . The standard deviation value is 7.17801 . The maximum value is 40.00 and the minimum value is 14.00 .

3. Teachers Performance (Y)

The average teacher performance score was 36.2000 . The standard deviation value is 7.53279 . The maximum value is 40.00 and the minimum value is 1 .

\section{B. Hypothesis Test}

The process of testing the hypothesis is carried out using multiple correlation analysis, which is to find the coefficient of influence between one variable on another variable, either individually or collectively. The calculation process is carried out with the help of SPSS 20.00. From the calculation, the results of the correlation coefficient for each variable will be obtained.

In this study, there are three hypotheses and tested in simple regression testing, the data used in this test are teacher performance (Y), teacher professional training (X1) and learning evaluation techniques (X2). The 
hypothesis of this study is that the first hypothesis is that there is a direct influence between teacher professionalism and learning evaluation techniques on teacher performance in madrasah.

The second hypothesis is that there is a direct influence between professional teachers on teacher performance in madrasah. The third hypothesis is that there is a direct influence between learning evaluation techniques on teacher performance in madrasah. From the results of multiple regression analysis, as listed in the following table, it can be analyzed:

Tabel 1.Model Summary

\begin{tabular}{|c|c|c|c|c|}
\hline Model & $\mathrm{R}$ & R Square & $\begin{array}{c}\text { Adjusted R } \\
\text { Square }\end{array}$ & $\begin{array}{c}\text { Std. Error of } \\
\text { the Estimate }\end{array}$ \\
\hline 1 & $.519^{\mathrm{a}}$ & .269 & .148 & 6.95420 \\
\hline
\end{tabular}

: (Constant), X2, X1

b. Dependent Variable: Y

Based on the table above, the $\mathrm{R}$ number is obtained, namely the multiple correlation between teacher professionalism and learning evaluation techniques on teacher performance in madrasahs of 0.519 . These results indicate that the relationship between teacher professionalism and learning evaluation techniques on teacher performance has a moderate effect. While the $\mathrm{R}$ square or the coefficient of determination is 0.269 or $26.9 \%$, this indicates that the percentage of the contribution of the influence of the independent variables (teacher professional and learning evaluation techniques) to the dependent variable (teacher performance) is $26.9 \%$, while $73.1 \%$ influenced by other factors.

The following is a table which is the result of the calculation of multiple regression analysis of the variable teacher performance on teacher professionalism and learning evaluation techniques. Next will be tested the significance and linearity of the regression. This regression significance test needs to be done to ensure conclusions are drawn.

Tabel 2.ANOVA

\begin{tabular}{|cc|c|c|c|c|c|}
\hline \multicolumn{1}{|c|}{ Model } & $\begin{array}{c}\text { Sum of } \\
\text { Squares }\end{array}$ & df & $\begin{array}{c}\text { Mean } \\
\text { Square }\end{array}$ & F & Sig. \\
\hline $1 \quad$ Regression & 214.070 & 2 & 107.035 & 2.213 & $.152^{\mathrm{a}}$ \\
& & & & & \\
& Residual & 580.330 & 12 & 48.361 & & \\
Total & 794.400 & 14 & & & \\
\hline
\end{tabular}

a. Predictors: (Constant),

$\mathrm{X} 2, \mathrm{X} 1$

b. Dependent Variable: Y

From the calculation results in the table above, it is obtained a significance value of 0.152 , this means that the calculated significance value is greater than the value of $\alpha=0.05$, thus it can be concluded that the $\mathrm{Y}$ regression on $\mathrm{X} 1$ and $\mathrm{X} 2$ is significant at the level of $\alpha=0.05$. In connection with this result, it can be said that the regression direction coefficient is real, so that the multiple regression equation obtained has meaning. The regression equation $\mathrm{Y}=18.751+0.234 \mathrm{X} 1$ $+0.292 \mathrm{X} 2$ shows that every 1 point increase in teacher professionalism will be followed by an increase in teacher performance of 0.234 and every 1 point increase in learning evaluation will be followed by an increase in teacher performance of 0.292 with a constant value of 18.751 .

Meanwhile, the equation of the regression line is presented as follows:

Tabel 3. Coefficients

\begin{tabular}{|c|c|c|c|c|c|c|}
\hline \multirow{2}{*}{\multicolumn{2}{|c|}{ Model }} & \multicolumn{2}{|c|}{$\begin{array}{c}\text { Unstandardized } \\
\text { Coefficients }\end{array}$} & \multirow{2}{*}{\begin{tabular}{|c|}
$\begin{array}{c}\text { Standard } \\
\text { ized } \\
\text { Coeffici } \\
\text { ents }\end{array}$ \\
\\
Beta
\end{tabular}} & \multirow[b]{2}{*}{$\mathrm{t}$} & \multirow[b]{2}{*}{ Sig. } \\
\hline & & B & $\begin{array}{l}\text { Std. } \\
\text { Error }\end{array}$ & & & \\
\hline & (Constant) & 18.751 & 9.327 & & 2.010 & .067 \\
\hline & $\mathrm{X} 1$ & .234 & .248 & .298 & .946 & .363 \\
\hline & $\mathrm{X} 2$ & .292 & .331 & .278 & .883 & .395 \\
\hline
\end{tabular}

a. Dependent Variable: Y 
From the results of the regression analysis above, it can be seen that the $t$ value is as shown in the coefficient table, which is equal to 0,363 and 0.395 . nk- 1 or 15-2-1 = 12. With a 2-sided test ( significance $=0.025$ ) the results obtained for t table are 2.179.

The test criteria are: Ho is accepted if - $\mathrm{t}$ table $\leq \mathrm{t}$ count $\leq$ table, Ho is rejected if - $\mathrm{t}$ count $<-\mathrm{t}$ table or $\mathrm{t}$ count $>\mathrm{t}$ table. Value $-\mathrm{t}$ table $\leq \mathrm{t}$ count $\leq$ table $(0.363 \leq$ 2.179 and $0.395 \leq 2.179)$, thus $\mathrm{H}_{0}$ is accepted and $\mathrm{H} 1$ is rejected, which means that there are no professional teachers and learning evaluation techniques together on teacher performance.

\section{The Discussion of Research Result}

1. Teacher professional activities on teacher performance

Teacher professional activities are carried out solemnly and are running well. This activity is carried out in order to improve teacher performance as measured by professionalism such as pedagogical, social, personal and professional competence. From the activities carried out, it is obtained $\mathrm{R}$ of $0.471 \mathrm{a}$ which indicates that the professional influence of teachers on teacher performance is 0.471 which indicates a moderate effect.

The coefficient of determination is 0.222 or $22.2 \%$, indicating that the percentage of the contribution of the influence of teacher professionalism on teacher performance is $22.2 \%$ so that $77.8 \%$ is determined by other factors.

The influence of the professional activities of teachers on teacher performance obtained a significance value of. 0.076b.0.076> 0.05. So from these results, it shows that teacher professionalism activities have no positive and significant impact on teacher performance.

Maimunah's research (2017) states that the activities of increasing professionalism carried out by him with the training method can increase teacher professionalism, which was initially obtained in cycle I by $59 \%$ in a fairly good category and in cycle II it increased to $88 \%$ in the very good category.

Rakib, et al (2017) added an explanation that with training to partially increase teacher professionalism will positively and significantly affect teacher professionalism in carrying out their duties.

1. Extension activities on learning evaluation techniques on teacher performance Counseling on learning evaluation techniques is a series of activities to increase teacher competence, namely from the pedagogical or teaching side, especially in the field of learning planning in which there is an evaluation of learning.

From these activities, after being given a questionnaire to the teachers who participated in these activities, an $R$ value of $0.464 \mathrm{a}$ was obtained, which indicates that the activity of counseling on learning evaluation techniques on teacher performance was 0.464 . The results of this hypothesis test indicate a moderate effect.

The coefficient of determination is $21.5 \%$, this percentage contributes to the extension activities of learning evaluation techniques on teacher performance, while $78.5 \%$ is influenced by other factors.

The influence of learning evaluation technique activities on teacher performance is obtained sig. 0.082.0.082> 0.05 , which indicates that there is no significant influence between the activities of learning evaluation techniques on teacher performance. So the conclusion is that there is no positive and significant effect of learning evaluation technique activities on teacher performance.

Based on the results of research by Rindarti (2018) which concludes the results of their activities that with ongoing mentoring activities in this case providing directions along with guidance is proven to increase teacher activity in developing learning tools at Madrasah Aliyah in Jakarta. 
The results of Sa'bani's (2017) research activity also increased the professional competence of MTs Muhammadiyah Wonosari teachers in preparing learning plans through training activities.

In the development of learning devices, there is an aspect of assessment or how the technical evaluation is carried out, so that training activities to make learning evaluation designs can improve teacher performance in carrying out their duties as learning evaluators properly.

2. Teacher professional activities and learning evaluation techniques on teacher performance

These activities both want to see the extent to which activities are related to teacher performance. obtained $\mathrm{R}$ value of $0.519 \mathrm{a}$ or 0.519 which shows the influence of teacher professionalism activities and learning evaluation techniques have a moderate effect.

The coefficient of determination is 0.269 or equal to $26.9 \%$, as a percentage of the contribution of the influence of teacher professional activities and learning evaluation techniques on teacher performance. The remaining percentage of $73.1 \%$ is contributed by the influence of other factors.

Teacher professional activities and learning evaluation techniques on teacher performance get a significance value of $0.152>0.05$. This value indicates that there is no significant influence between teacher professionalism activities and learning evaluation techniques on teacher performance in Madrasah.

So the conclusion is that there is no positive and significant influence between teacher professional activities and learning evaluation techniques on teacher performance. As research conducted by Rahmawati (2015), teacher competency training can improve teacher professionalism in carrying out tasks positively and significantly at SMK Negeri Tiga Palu.

This is also confirmed by the results of research and hypothesis testing conducted by Gala, et al. (2017), that training activities can significantly affect teacher teaching performance and teaching motivation of science teachers in SMPs in Poso City.

\section{CONSLUSION}

From the explanation of the implementation of the research above, it can be concluded that:

1. There is no positive and significant effect of teacher professional activities on teacher performance in Mifathul Falah madrasah schools.

2. There is no positive and significant influence between teacher professional activities and learning evaluation techniques on teacher performance in Mifathul Falah madrasah schools.

\section{REFERENCES}

Ernawati, RiniSafitri. (2017). Analisis Kesulitan Guru Dalam Merancang Rencana Pelaksanaan Pembelajaran Mata Pelajaran Fisika Berdasarkan Kurikulum 2013 Di Kota Banda Aceh. Jurnal Pendidikan Sains Indonesia (Indonesian Journal of Science Education) Vol.5, No.2, hlm. 4956, http://jurnal.unsyiah.ac.id/jpsi. DOI: $10.24815 /$ jpsi.v5i2.9817

Gunawan, Rudy. 2011. Implementasi Pengembangan Profesionalisme Bagi Guru Bersertifikat Pendidik SOCIUS Jurnal Pendidikan IPS (4).

http://repository.uhamka.ac.id/12/

Gala, I. Novayanti, A. Ramadhan dan A. Rede. 2017. Pengaruh pelatihan dan motivasi kerja terhadap Kinerja mengajar guru IPA di smp se-Kota Poso. Jurnal Mitra Sains Vol.5No.2. 
http://jurnal.pasca.untad.ac.id/inde x.php/MitraSains/article/view/71

Musfah, Jejen. (2015). Meningkatkan Kompetensi Guru dengan Pelatihan. Jakarta: Grafindo

Mawardi. 2019. Optimalisasi Kompetensi Guru Dalam Penyusunan Rencana Pelaksanaan Pembelajaran Jurnal Ilmiah DIDAKTIKA Agustus 2019 VOL. 20, NO. 1, 69- 82 https://jurnal.arraniry.ac.id/index.php/didaktika/art icle/view/3859

Mulyasa, E. (2007). Standar Kompetensi dan Sertifikasi Guru. Bandung: Remaja Rosdakarya.

Rahmawati, Sri. 2015. Pengaruh pelatihan, pengalaman mengajar dan kompensasi terhadapprofesionalisme guru di smk negeri 3 Palu. Jurnal katalogis. Vol.3, No. 2.

http://jurnal.untad.ac.id/jurnal/inde X.php/Katalogis/article/view/6482

Rakib, Rombe, Yunus. 2017. Pengaruh Pelatihan Dan Pengalaman Mengajar Terhadap Profesionalitas Guru. Jurnal Ad'ministrare, Vol. 3 No. 2, 2017
file:///C:/Users/DigiCom88/Downl oads/2574-6139-1-PB.pdf

Rindarti, Eni. 2019. Peningkatan Kompetensi Guru dalam Mengembangkan RPP Kurikulum 2013 Revisi $2017 \quad$ Melalui Pendampingan Berkelanjutan di MA Binaan Kota Jakarta Pusat Tahun Pelajaran 2017/2018. Jurnal Penelitian Kebijakan Pendidikan Volume 11, Nomor 2, Agustus 2018.http://jurnalpuslitjakdikbud.k emdikbud.go.id/litjak/article/view/ 221

Sa'bani. F.2017. Peningkatan Kompetensi Guru dalam Menyusun RPP melalui Kegiatan Pelatihan pada MTs Muhammadiyah Wonosari. Jurnal Pendidikan Madrasah, Volume 2, Nomor 1, Mei 2017. http://ejournal.uin suka.ac.id/tarbiyah/index.php/JPM/ article/view/1429/1218

Sagala, Syaiful. 2009. Kemampuan Profesional Guru dan Tenaga Kependidikan. Bandung: Alfabeta.

Sugiyono. (2014). Metode Penelitian Kombinasi (Mixed Methods). Bandung: Alfabeta. 